\title{
ON THE FAILURE OF THE PLYMOUTH HERRING FISHERY
}

\author{
By D. H. Cushing \\ Fisheries Laboratory, Lowestoft \\ (Text-figs. I-IO)
}

In the winter of 1930-3I it was noticed that the winter maximum of phosphorus at the International Station E I was less than the average of the previous ro years. The change which has persisted ever since was associated with certain biological events (Kemp, I938) of which the most important was the failure of the Plymouth herring fishery between I93I and 1935, due to a failure of recruitment. Other changes included the replacement of Sagitta elegans by $S$. setosa; this change of a conspicuous and long-lived plankton indicator species was accompanied by changes of other indicators, implying a change of communities. At the same time a reduction was found in the quantity of macroplankton, as sampled by the wide-meshed ring-trawl. Certain species of medusae were no longer caught and the numbers of late summer medusae were reduced by four times (Russell, 1938b). A hint of a further change can be found in Russell $(1939 b)$ where he noticed that 'the western end of the Channel has been characterized by a great number of pilchard eggs and a general poverty of plankton indicators, including both species of Sagitta'.

From re-examination of the evidence available, including some new material hitherto unpublished, it is clear that a significant increase in pilchard occurred. The evidence for this increase is found in the regular ring-trawl catches taken off Plymouth, in marked contrast to the decline in the Plymouth herring fishery, which had no detectable effect on the numbers of young clupeids caught during the winter. The relative importance of the increase in pilchard leads to the hypothesis that the Plymouth herring fishery failed because the stock became reduced in competition with the pilchard population of the Western Channel, and that the change in the winter maximum of phosphorus was the effect of an increase in the number of pilchards.

I am grateful to Dr F. S. Russell, F.R.S., Director of the Marine Laboratory at Plymouth, for his permission to use some of Ford's unpublished data from 1932 to 1935 , and to use other unpublished data on the occurrence of pilchard eggs in the Young Fish Trawl catches before I935. 


\section{THE CHANGE IN ABUNDANCE OF THE POPULATION OF PILCHARDS}

Once a week from 1924 to I938, a ring-trawl was hauled for half an hour 2 miles east of Eddystone. In the results published (Russell, I930, I935, I936, I937, I938a, I939 $a$ ), the clupeid larvae were not identified, but those caught in May, June and July may be classified as pilchards. Russell (I935) has written (p. 156): ' . . . it is likely, therefore, that any clupeid occurring after the increase of sprat in February, March and April, will be pilchard right up to the end of the year when young herring begin to appear in December'.

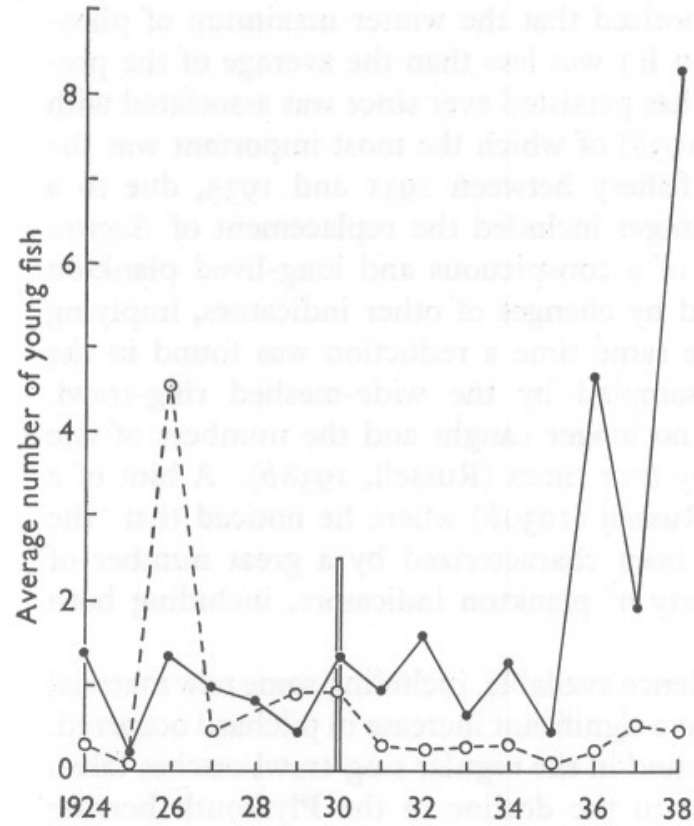

Fig. I

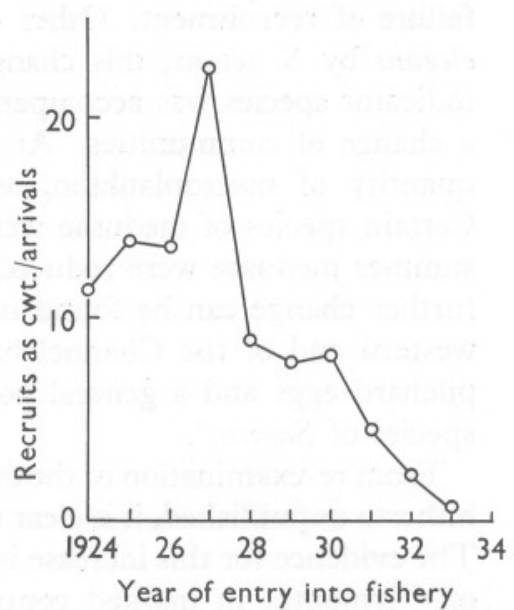

Fig. 2

Fig. I. The numbers of young clupeids, assumed to be pilchards, caught off the Eddystone from May to July in $1924-38$. The pecked line is the number of mackerel and horse mackerel ('scads').

Fig. 2. The numbers of recruit herring as at 3 years of age from 1924 to 1934 .

Fig. I (from Cushing, 1957) shows the average number of young clupeids in May, June and July in each year for a long series from I924 to I938. Pilchard eggs were first observed in large numbers in the ring-trawl catches in the summer of 1935 (personal communication; Dr F. S. Russell); from Fig. I, it will be noticed that the larvae first became abundant in 1936. At this time pilchards matured at between 3 and 5 years old; and from fat and maturity studies (Hickling, I945), it is likely that a pilchard which ripened late in its 
fourth summer spawned in its fifth (with four winter rings on its scales). The age-distributions given in Appendix II (p. 8I6) show that recruitment is spread over several age-groups. Fish spawned in the summer of 1930 may have matured by the summer of 1934 as three-ringers; later recruits would have appeared in 1935 and 1936 . From the growth rate (see Appendix II), and from the pattern of recruitment, it is not likely that the full spawning potential was reached before 1936. Assuming that the outburst of eggs and larvae in 1936 really represents an increase in the adult stock, it is likely that the increased numbers of adults were born about 1930 or I93I. Dr Russell (personal communication) recorded pilchard eggs during the period I930-35 as follows:

$\begin{array}{ccccc}\text { I930 } & \text { I931 } & \text { I932 } & \text { I933 } & \text { I934 } \\ 652 \text { (Nov.) } & \text { I34 (Oct.) } & \text { present (Oct.) } & \text { Nil } & \text { Many pilchard } \\ & & & & \text { (July and Sept.) }\end{array}$

In 1935 he started to comment on the abundance of pilchard eggs, and in I936 the number of pilchard eggs reached 5000 (Table I). Thus the increase in pilchard eggs in summer agrees with the spreading of recruitment over perhaps three years. This suggests a more gradual increase in the stock than that shown by the larvae, which is a sharp increase in 1936 ; hence the number of pilchard eggs is probably a more precise index of stock, but there is a longer series of observations on pilchard larvae.

\section{THE RELATIONSHIPS BETWEEN HERRING RECRUITMENT, NUMBERS OF PILCHARDS AND THE WINTER MAXIMUM OF PHOSPHORUS}

Because the increase in pilchard stock appears to have started in 1930-31, it was decided to investigate its bearing on the other events that took place at that time. Three series of data were used: (I) on herring recruitment, (2) on numbers of pilchard eggs, and (3) on the maxima of winter phosphorus. They are set out as time series in Table I. The values of herring recruitment (as calculated in Appendix I) are given as cwt./arrival at 3 years of age, but they are dated to the year of birth, i.e. as year-classes. The numbers of pilchard eggs are those observed in ring-trawl catches taken 2 miles east of Eddystone in May and June (Russell, 1930, 1935, 1936, 1937, 1938a, 1939a, 1947; Corbin, 1948, I949, I95I and personal communication; Southward, personal communication). The observations of phosphorus were taken at International Station EI and are expressed in $\mu \mathrm{g}$ at. P/1. (Cooper, I938; 1948, in which Station $\mathrm{X}_{3}$ is substituted for $\mathrm{EI}_{\mathrm{I}}$; Atkins, I953, corrected for salt error; Armstrong, 1954, 1955, 1957, 1958).

Figs. 2 and 3 show the trend in herring recruitment from I92I to I930 (in year-classes) and the trend in winter phosphorus from I92I to I937. It appears that the decline in herring recruitment started long before the I930 year-class, 
possibly with the 1925 year-class and certainly with the 1928 one. The change in winter phosphorus is best interpreted as a declining trend. This conflicts with the view of Kemp (1938), who said that the change in 1930-1931 was a sudden one and suggested that the recruitment to the Plymouth herring fishery failed as a consequence. This latter interpretation must be considered unlikely because the major decline in herring recruitment started before I930-I93I.

TABLE 1. THE DATA ANALYSED

\begin{tabular}{|c|c|c|c|}
\hline Year & $\begin{array}{l}\text { Herring } \\
\text { recruitment } \\
\text { (cwt./arrival } \\
\text { at age 3, } \\
\text { dated to year } \\
\text { of birth, } \\
\text { December) }\end{array}$ & $\begin{array}{c}\text { Pilchard eggs } \\
\text { (monthly averages added } \\
\text { for May and June; } \\
2 \text { miles E. of Eddystone) }\end{array}$ & $\begin{array}{c}\text { Winter phosphorus } \\
(\mu \mathrm{g} \text { at. } \\
\left.\mathrm{P} / \mathrm{l} \text {. at } \mathrm{E}_{1}\right)\end{array}$ \\
\hline I92I & II 4 & No observations & $\begin{array}{l}0.65 \\
(1921-22)\end{array}$ \\
\hline I922 & I3.8 & No observations & 0.71 \\
\hline I923 & 13.5 & No observations & 0.71 \\
\hline I924 & $22 \cdot 5$ & (Present at $\mathrm{E}_{1}$, Apr.)* & $0.6 \mathrm{I}$ \\
\hline 1925 & $8 \cdot 8$ & (Present at $\mathrm{E}_{2}$, July)* & 0.76 \\
\hline 1926 & $7 \cdot 7$ & $\begin{array}{l}750 \text { ( } 2 \text { miles west of } \\
\text { Eddystone) } \dagger\end{array}$ & 0.55 \\
\hline I927 & $8 \cdot 0$ & (Present in July) $†$ & 0.69 \\
\hline I928 & 4.4 & $?$ & 0.69 \\
\hline I929 & $2 \cdot 2$ & $?$ & - \\
\hline I930 & 0.6 & 一 & 0.52 \\
\hline I93I & 一 & - & 0.47 \\
\hline I932 & - & - & 0.53 \\
\hline 1933 & - & - & 0.48 \\
\hline I934 & - & 一 & 0.42 \\
\hline I935 & - & - & 0.47 \\
\hline I936 & - & 5,000 & 0.48 \\
\hline I937 & - & 6,800 & 0.47 \\
\hline I938 & - & 6,100 & - \\
\hline I946 & - & 13,605 & 0.40 \\
\hline I947 & - & 12,226 & 0.45 \\
\hline I948 & - & 3,338 & 0.43 \\
\hline I949 & 一 & $78 \mathrm{I}$ & 0.51 \\
\hline I950 & - & 2,155 & 0.51 \\
\hline I95I & - & 2,490 & 0.46 \\
\hline 1952 & - & 10,946 & 0.45 \\
\hline I953 & - & 4,962 & 0.51 \\
\hline 1954 & - & No counts & 0.59 \\
\hline I955 & - & I,8I2 & 0.50 \\
\hline I956 & - & No counts & 0.47 \\
\hline I957 & - & $\begin{array}{r}8,650 \\
\end{array}$ & 0.44 \\
\hline 1958 & 一 & No counts & 0.54 \\
\hline
\end{tabular}

It might be thought possible that the decline in herring recruitment was associated with the decline in winter phosphorus; as waters became less potentially fertile, the chances of survival in the ensuing summer could well decrease. The number of herring recruits has been plotted against the value of winter phosphorus in the winter of hatching; the regression (Fig. 4) is not significantly different from zero $(P=0.53 ; n=9)$ and it comprises the 
evidence for the period I92I-I930. When the numbers of herring recruits are plotted against the value of phosphorus I year after the winter of hatching (see Fig. 5, which actually shows the plot made the other way), a surprising result emerges; the regression was highly significant $(P=0.01 ; n=9)$.

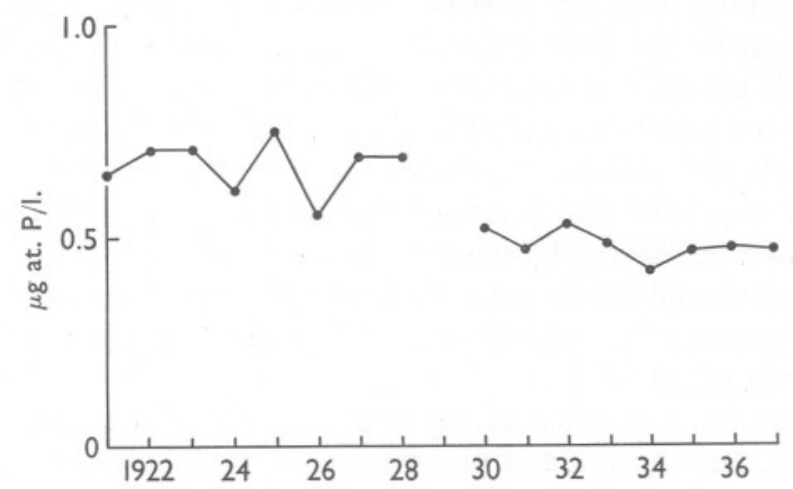

Fig. 3. Winter phosphorus at station EI from I92I to I937 (from Cooper, I938).

The year is that in which the winter began.

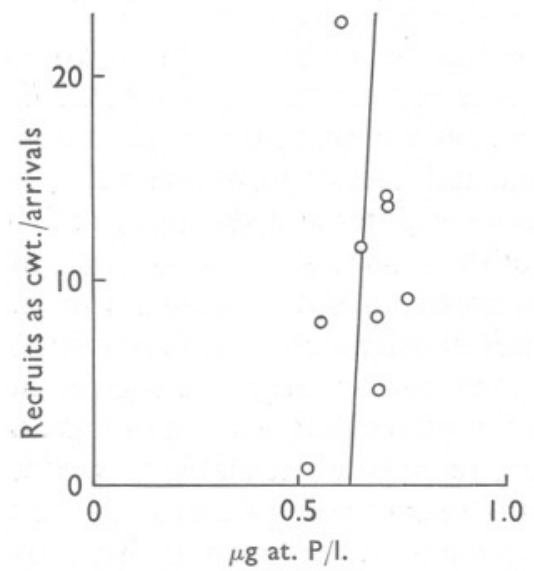

Fig. 4

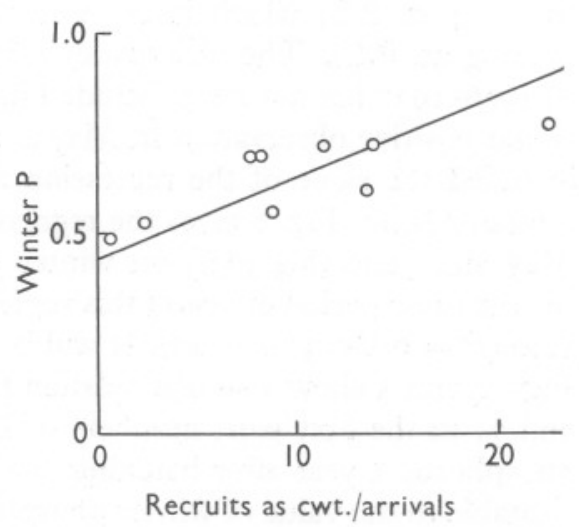

Fig. 5

Fig. 4. Regression of the number of herring recruits (3-year-olds) on winter phosphorus.

Fig. 5. Regression of winter phosphorus, I year after the herring recruits were hatched, on the number of recruits.

The evidence was compared for the same time period, I92I-I930. The contrast between the two regressions is striking, and it is the second one that requires explanation.

In general terms it appears that as the herring population declined in the early thirties, so the pilchard population increased, noticed as an increase in 
eggs and larvae in 1935 and 1936 . This is interpreted as ancrease in adult stock, originating from eggs and larvae born about I930 or I93I. No increase in eggs or larvae caught by the Young Fish Trawl occurred between 1930 and 1935, and so if the increase in the adult stock of pilchards were a true one, it must have sprung from an increased survival of larvae older than those generally caught by the Young Fish Trawl. It is of course possible that the adult pilchards came from somewhere else in 1935 and 1936 . However, it is possible that the increased survival of pilchard larvae in 1930 and I93I is associated with the striking regression of herring recruitment on winter phosphorus I year after the herring were hatched; the reason may be that pilchards spawn in May and June and the increased survival of their larvae from I930 to I93 I could be interpreted as an end-point to competition between herring and pilchard, associated with the decline in herring recruitment which had been taking place.

Fig. 6 shows the regression of log numbers of pilchard eggs observed in May and June, and the value of phosphorus in the following winter (for the period I936-I957, excluding I954 and I956). The regression is significantly different from zero $(P<0.01 ; n=13)$ and shows by extrapolation that if the numbers of pilchard eggs became reduced to low levels again $(<\mathrm{IOO})$, one would expect to find high values of phosphorus in the subsequent winter ( $0.65 \mu \mathrm{g}$ at. $\mathrm{P} / 1$., which is close to the average value from I92I to I928, $0.66 \mu \mathrm{g}$ at. $\mathrm{P} / 1$.). The observation of 750 eggs in 1926 with $0.55 \mu \mathrm{g}$ at. $\mathrm{P} / 1$. in $1926-1927$ has not been included in the regression because it is based on a single positive observation in May and June and four negative ones; if it is included the slope of the regression decreases slightly and the variance increases a little. Fig. 7 gives the regression of the numbers of pilchard eggs in May and June (log plot) on winter phosphorus, in the preceding winter, for the same period of years; this regression is not significantly different from zero $(P=0.2-0.3 ; n=\mathrm{I} 2)$. It will be seen that the two regressions given in Figs. 4 and 5 show a similar relation to each other as those shown in Figs. 6 and 7 ; in the first pair, numbers of herring recruits are relatable to winter phosphorus I year after hatching, and in the second pair pilchard eggs are relatable to the value of winter phosphorus 6 months after hatching. There is no relation between the numbers of herring recruits and the winter phosphorus in the year in which they were hatched, nor between that winter phosphorus value and the numbers of newly hatched pilchard eggs found 6 months later. The important point here is that both herring and pilchard indices are correlated with the same value of winter phosphorus, that of the following winter. There are two possible conclusions: (I) that both herring and pilchard are correlated with winter phosphorus; (2) that herring or pilchard is correlated with winter phosphorus, and that the other (pilchard or herring) is not correlated with winter phosphorus, but with the first.

It might be questioned here why the numbers of pilchard eggs have been used 
in the analysis and not the numbers of pilchard larvae, for which there is more information. The reason is that the variability of regressions using pilchard larvae is very high and the distinction in the correlations given above does not appear. The larvae caught quantitatively by the Young Fish Trawl are not very old-about a month at the most-and so it is suggested that number of larvae is an index of stock, like the number of eggs, but not such a good one because of the effects of mortality and escape.

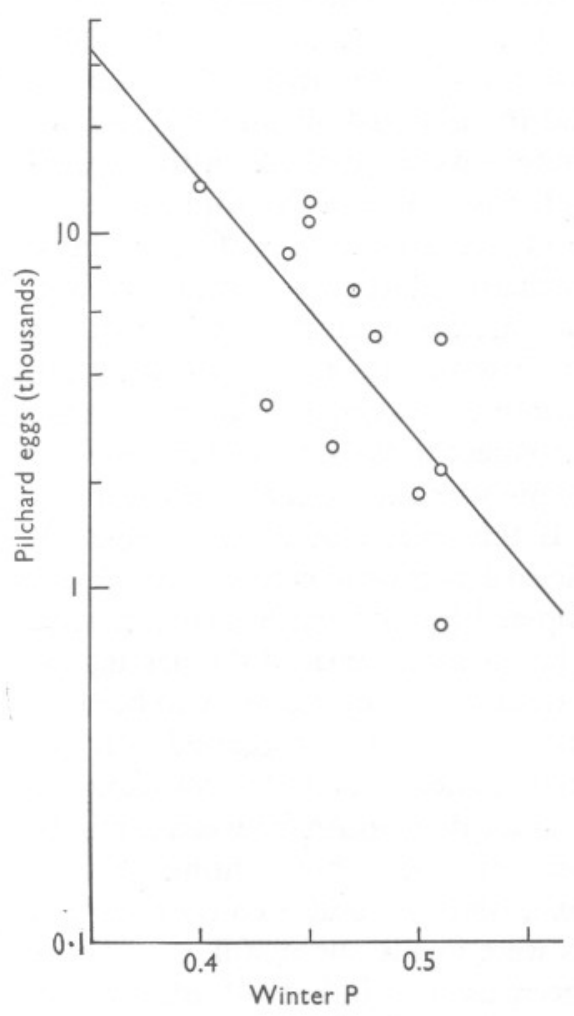

Fig. 6

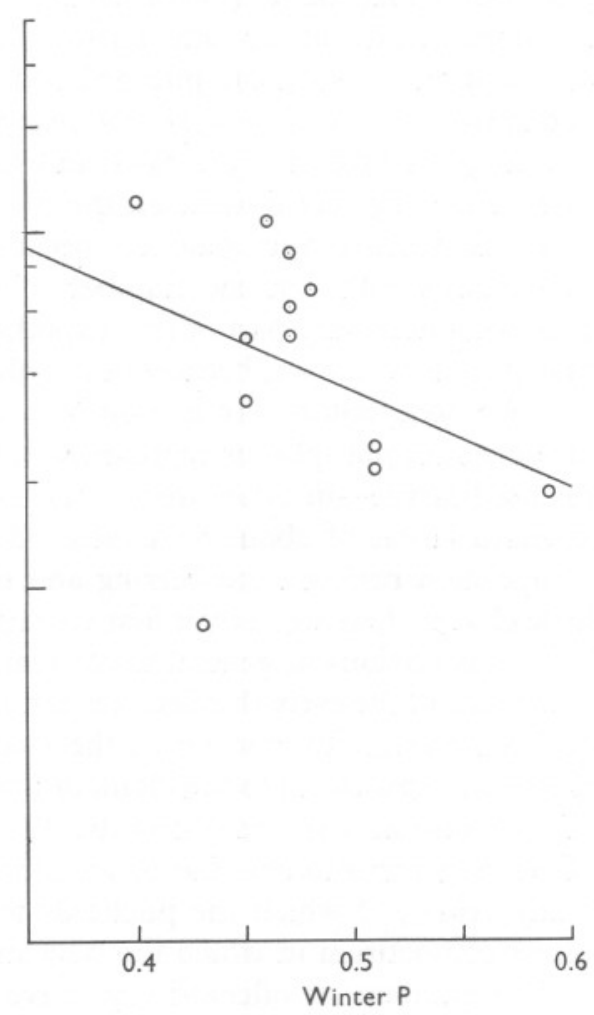

Fig. 7

Fig. 6. Regression of log numbers of pilchard eggs on phosphorus (in $\mu \mathrm{g}$ at. $\mathrm{P} / \mathrm{l}$ ) in the subsequent winter. (Regression significantly different from zero: $P=0.02-0.01$.)

Fig. 7. Regression of log numbers (thousands) of pilchard eggs on phosphorus (in $\mu \mathrm{g}$ at. $\mathrm{P} / 1$.) in the preceding winter. (Regression not significantly different from zero: $P=0.3-0 \cdot 2$.)

It seems likely that the low values of winter phosphorus from I930-3I to 1935-36 were associated with the possibly increased numbers of pilchards of a size large enough to dodge the Young Fish Trawl. It might be argued that the herring/phosphorus relation and the pilchard/phosphorus relation were independent, the pilchards coming in from 1934 to 1936 . This does not account 
for the low values of phosphorus from I930-3I to I934-36, when herring recruitment was non-existent (except for I930-3I). It is, however, reasonable to associate the low values of phosphorus during that period with the possibly improved survival of older pilchard larvae (perhaps 6 months old-large enough to escape the Young Fish Trawl), which would also explain the stock increase in 1935-36. If it were conceded that the low values of phosphorus in 1930-35 were associated with higher numbers of 6-month-old pilchard larvae, the decline of herring recruitment in the earlier years might be accounted for in the same terms. In other words, there would have been competition between the pilchard and the herring, the herring recruitment declining from 1925 or 1928 onwards and the pilchard obtaining a decisive advantage in I930 or I93I. Such an hypothesis would account for the regression of herring recruitment on the phosphorus values in the winters I year after the herring were hatched, because of the dependence of that winter phosphorus value on the number of pilchards hatched 6 months before. It is not a necessary part of this hypothesis that the significance of the winter phosphorus is known, because it is only a factor common to and connecting the two competitors. It is, however, tempting to suggest that the decline in the winter phosphorus represents an increment to the numbers of survived pilchard larvae-in other words, the lost phosphorus is locked up in living pilchard larvae of about 6 months old. If this were true then the stage of competition between the herring and pilchard populations would become a little clearer; herring in their first year competed with pilchards up to 6 months old. It is obvious in general terms that the pilchard replaced the herring off Plymouth in the early thirties; it is not noticed as an increase in catch because this is a minute proportion of the stock $(<\mathrm{I} \%)$. It is suggested that the failure of recruitment to the Plymouth herring fishery was really a consequence of competition with the pilchards. We cannot distinguish between a failure of herring recruitment due to an independent cause (but continuous over many years), of which the pilchards took advantage, and a continuous and direct competition in which the pilchards were finally successful.

The numbers of pilchard eggs have been used as indices of adult stock. It has been suggested above that differences in the subsequent value of winter phosphorus are really differences in the quantities of 6-month-old larvae. We have enough data to relate these differences to that stock, when the 6-month-old larvae have recruited and have become one of the dominant age-groups in it. Fig. 8(A) gives the regression of winter phosphorus on pilchard eggs 4.5 years later, which is the time from I930-3I to I935-36; there is no relationship, the slope not being significantly different from zero $(P=0.9 ; n=8)$. In Fig. $8(\mathrm{~B})$ is shown a regression of winter phosphorus on pilchard eggs 4.5 years later for the pre-war period and 3.5 years later for the post-war period, taking into account recruitment at an earlier age in the post-war period; there is a slight improvement in the relationship $(P=0.2$; 

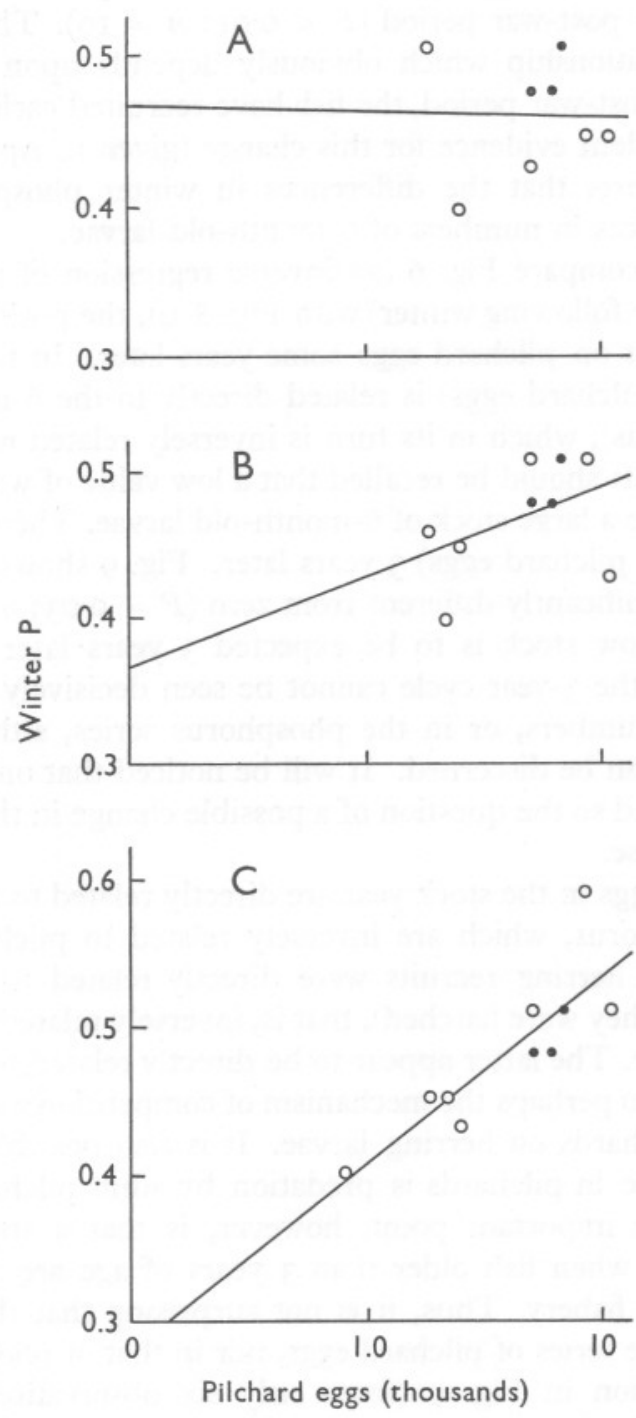

Fig. 8. A, Regression of winter phosphorus (in $\mu \mathrm{g}$ at. $\mathrm{P} / \mathrm{l}$.) on numbers of pilchard eggs 4.5 years later; pre-war observations are shown as black dots and post-war ones as open circles. (No significant difference from zero.) B, Regression of winter phosphorus on numbers of pilchard eggs 4.5 years later in the pre-war period (black dots) and 3.5 years later in the post-war period (open circles). (No significant difference from zero: $P=0 \cdot 2$.) c, Regression of winter phosphorus on numbers of pilchard eggs 4.5 years later in the pre-war period (black dots) and 2.5 years later in the post-war period (open circles). (Significant difference from zero: $P=<0.01$.) 
$n=9$ ), but by itself of no significance. A third regression (Fig. 8(c)) is of winter phosphorus on pilchard eggs 4.5 years later in the pre-war period and 2.5 years later in the post-war period $(P<0.0 \mathrm{I} ; n=\mathrm{IO})$. This is a clear and good positive relationship which obviously depends upon the assumption that, during the post-war period, the fish have recruited earlier in their lives. There is independent evidence for this change (given in Appendix II). This relationship suggests that the differences in winter phosphorus really do represent differences in numbers of 6-month-old larvae.

We must now compare Fig. 6 (an inverse regression of pilchard eggs on phosphorus in the following winter) with Fig. 8(c), the positive regression of winter phosphorus on pilchard eggs some years later. In the terms used so far, adult stock (pilchard eggs) is related directly to the 6-month-old larvae (winter phosphorus), which in its turn is inversely related to the adult stock some years later. It should be recalled that a low value of winter phosphorus is taken to indicate a large stock of 6-month-old larvae. Therefore adult stock was correlated (as pilchard eggs) 3 years later. Fig. 9 shows such a relationship, which is significantly different from zero $(P=0.03 ; n=7)$; when the stock is high, a low stock is to be expected 3 years later and vice versa. As a time series, the 3-year cycle cannot be seen decisively in the sequence of pilchard egg numbers, or in the phosphorus series, although some evidence of a cycle can be discerned. It will be noticed that only post-war data have been used and so the question of a possible change in the age of recruitment does not arise.

The pilchard eggs in the stock year are directly related to the 6-month-old larvae, as phosphorus, which are inversely related to pilchard eggs in the recruit year. The herring recruits were directly related to the phosphorus (in the year after they were hatched), that is, inversely related to the 6-monthold pilchard larvae. The latter appear to be directly related to the adult stock of pilchards, and so perhaps the mechanism of competition was a direct predation by adult pilchards on herring larvae. It is also possible that the cause of the 3-year cycle in pilchards is predation by adult pilchards on pilchard larvae. The more important point, however, is that a strict 3-year cycle should not occur when fish older than 3 years of age are found as a good proportion of the fishery. Thus, it is not surprising that the cycle appears neither in the time series of pilchard eggs, nor in that of phosphorus. Therefore, the correlation in Fig. 9 (from only six observations) suggests the presence of a cycle, but does not prove its existence, although there was a three-year gap in the observations. 


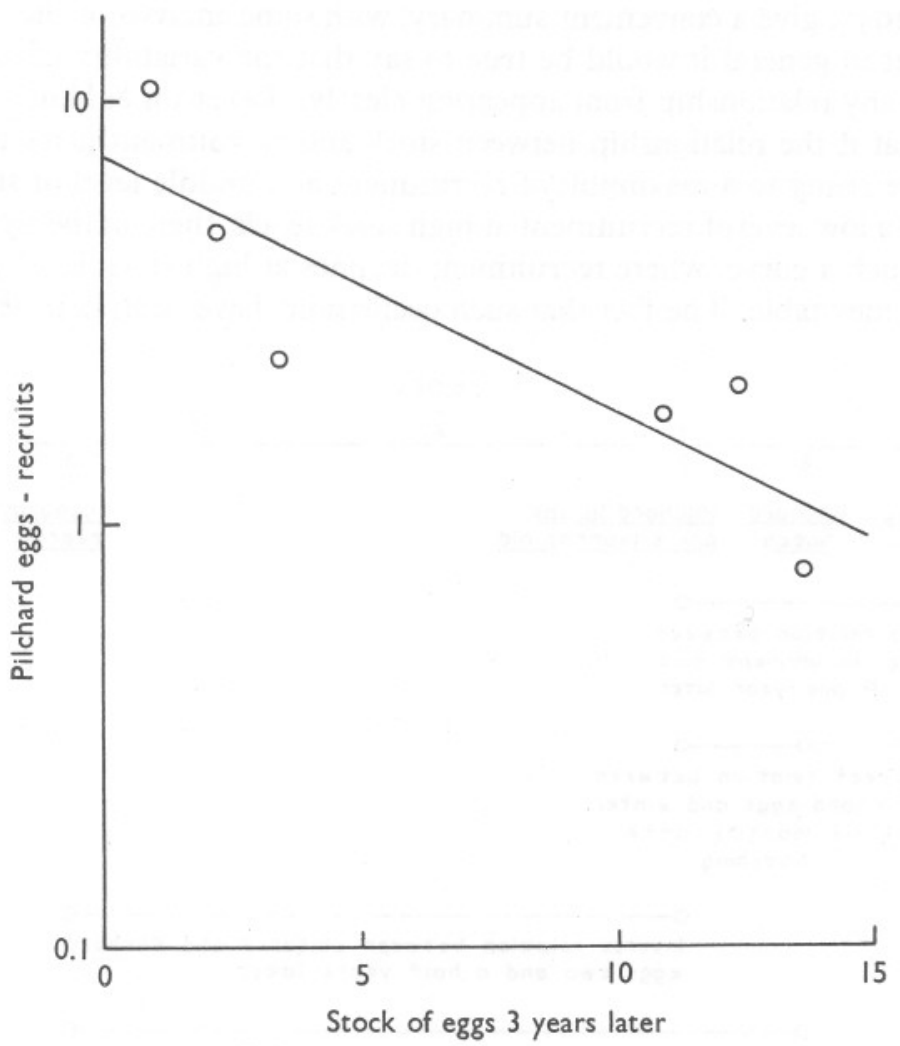

Fig. 9. Regression of $\log$ numbers (thousands) of pilchard eggs on pilchard eggs 3 years later. (For difference from zero: $P=0.03$.)

\section{DISCUSSION}

The arguments presented are given in summary and diagrammatic form in Fig. Io. The simplest interpretation of the relations is that differences in winter phosphorus are caused by differences in numbers of 6-month-old pilchard larvae; the development of the argument on stock and recruitment depends on this interpretation and reaches the point at which an independent and cyclic relation was discovered. This discovery strengthens the hypothesis that the decline of herring recruitment in the Plymouth herring fishery was associated with competition from pilchards. The association would have been quite decisive had there been independent evidence that the differences in winter phosphorus were truly associated with differences in 6-month-old pilchard larvae. This cannot be established and so the association must remain quite hypothetical.

Evidence of a relationship between stock and recruitment exists (Beverton 
\& Holt, 1957, give a convenient summary, with some analysis of the available data); but in general it would be true to say that the variability of such data prevents any relationship from appearing clearly. Beverton \& Holt's analysis shows that if the relationship between stock and recruitment takes the form of a curve rising to a maximum of recruitment at a middle level of stock and falling to a low level of recruitment at high stock levels, then on the right-hand limb of such a curve, where recruitment declines at high stock levels, oscillations are inevitable. The fact that such oscillations have been detected in the

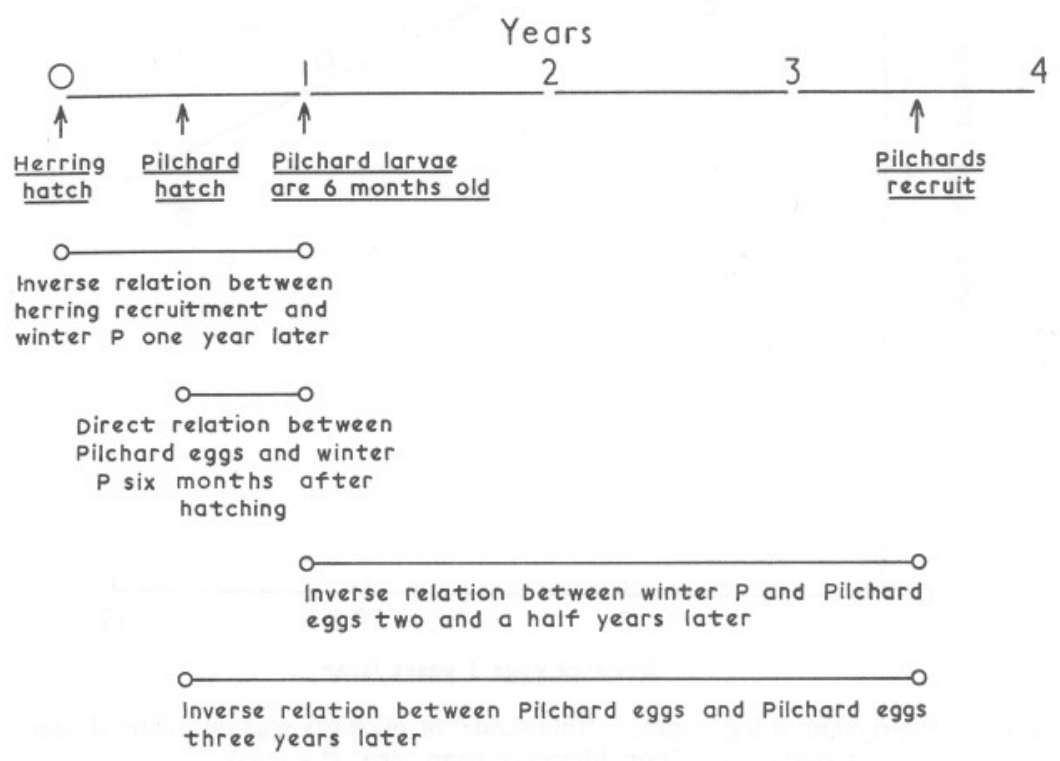

Fig. Io. The interrelationships of the regressions used.

case of the pilchard suggests that the stock and recruitment relationship is working on the high level of stock; indeed Fig. 9 can be regarded as part of the curve of recruitment on stock, showing the right-hand limb to the curve.

The cause of oscillation possibly is effective between the age of 6 months and recruitment. It was suggested that it might occur if adults ate larvae (Ricker, I958); Beverton (I96I) has suggested the term 'over-compensation' for such an effect in which above a certain level of abundance of present stock, the number of surviving progeny is reduced.

It was noted above that Kemp has interpreted the events of 1930-3I as an abrupt change and that the decline in winter phosphorus from I924 to I938 is here interpreted as a gradual change. It is likely that both are true in different senses. The change-over from rich to poor macroplankton, and from $S$. elegans to $S$. setosa, with its associated indicators, appeared to be abrupt. But Russell (1939) has pointed out that both species of Sagitta declined in 
1936, which was the year of the pilchard increase-which is some evidence of gradual change. If, however, the decline in phosphorus is interpreted as a steady increase in 6-month-old pilchard larvae, this is a gradual change in competition with the herring, with a decisive step in 1930-3I. The evidence that differences in phosphorus were associated with differences in numbers of 6-month-old larvae really rests on the relations with pilchard eggs both as parent stock and as subsequent recruits (Figs. 8(c) and 9). Therefore it is likely that the stock of 6-month-old larvae did increase in 1930-3I and that the changes in macroplankton and in plankton indicators came as a consequence. Thus the change in macroplankton might also have been a competitive change, the large and predatory jellyfish, etc., having been eliminated by the growing pilchards. A further consequence is that the plankton indicators have indicated not a change in water masses, but a change in communities as a result of competition.

There appears to have been a change-over from a community of herring, rich macroplankton, $S$. elegans and high winter phosphorus, to one of pilchards, poor macroplankton, $S$. setosa and low winter phosphorus. We know that there is an oscillation in the pilchard population and it is tempting to suggest that when the oscillation reaches a nadir, the quantity of 6-month-old pilchards is low and the winter phosphorus is high. In 1954-55 this happened, and in 1955, 1956 and 1957, young herring were caught in the Western Channel by trawlermen working from Brixham. It may well be that it is the pilchard oscillations that allow the herring population to obtain an advantage. In 1915 the winter phosphorus values were low (Matthews, 1917) and in I9I7-I 8 the Plymouth herring fishery increased sharply in catch per unit effort. Is it possible that the remarkable point was not so much the decline of the Plymouth herring fishery in the early thirties, but its rise from I9I8 onwards? It is possible that the present Dunmore fishery is subject to the same sort of effect, lying as it does on the edge of the pilchard distribution.

The winter maximum of phosphorus has been considered as an index of potential fertility. The argument presented in this paper does not necessarily deny this, but suggests that the proportion of living material in any phosphorus budget can be fairly high and so the winter maximum of phosphorus could only be at best a partial index of potential fertility. It has, however, been suggested elsewhere (Cushing, I959 $a$ ) that in certain tropical regions where phosphorus is very low all the year round the greater proportion of phosphorus is locked up in living material all the time. It was further suggested that this took place in a steady-state system and that the winter phosphorus was found in an unbalanced system of production, and that its magnitude was a rough and ready index of the backlash possible in such a system. If this were true it would imply that the real use of such measurements lay in the interpretation of changes in populations within different productive cycles, rather than in the measurement of potential fertility. 
This paper does not seek to provide a factual account of the failure of the Plymouth herring fishery; this has already been done by Ford (I933). An hypothesis has been set up, postulating that the failure of recruitment to the herring fishery in the early thirties was an effect of competition with the pilchard population living in the same area. As such it is an alternative hypothesis to that put forward by Kemp (1938) to account for the biological changes that took place off Plymouth in 1930-3I. The weaknesses of the present hypothesis are as follows.

(I) The information on pilchard larvae from 1924 to 1935 provides no evidence of stock changes or of competition. Particularly from I93I to I935, no increase in pilchard larvae took place. It is true that pilchard eggs were observed in 1934 and 1935, as might be expected from an increasing adult stock with partial recruitment. Further it has been suggested that numbers of pilchard eggs constitute a more precise measure of stock than numbers of pilchard larvae, and hence correlations with very low numbers of observations might be expected with eggs but not with larvae.

(2) The change of age of first recruitment is deduced from Table 3 in Appendix II for 1949-52; of these years, there is only one before the postulated change-r949. The change in length for age at the same time supports this conclusion, as does the treatment in Figs. $8(\mathrm{~A}-\mathrm{C})$. But the independent evidence of a change of recruitment would really require a series of agedistributions before 1950 and not one only.

(3) There is a lack of direct evidence from I93 I to I935. It will be recalled that herring recruitment was correlated with the winter phosphorus one year after birth from 1920 to 1930 , and pilchard eggs were correlated with winter phosphorus 6 months after birth from I935 to I958. It is possible that the two events are separate ones and that the low winter phosphorus from I93I to I935 was associated with a third independent factor. However, a regression has been established between winter phosphorus and pilchard eggs 2.5 years later, which means that the phosphorus must constitute a link between the pilchard stock and the pilchard recruits. It is reasonable then to assume that this link existed in 1930-35 and to name it 6-month-old larvae. On this point the whole hypothesis is simpler than that of three independent events. However, it is felt that even with these weaknesses there is sufficient coherence in it to justify serious consideration.

\section{SUMMARY}

An hypothesis has been erected to account for the failure of the Plymouth herring fishery and the associated biological events in the early thirties. It was found that the quantity of winter phosphorus was inversely related to the quantity of pilchard eggs 6 months earlier and directly to the quantity of herring recruits a year earlier. It is thought that the differences in quantities 
of winter phosphorus have represented differences in numbers of 6-month-old pilchard larvae; the winter phosphorus provides the link between herring recruitment and numbers of pilchard eggs, suggesting that there has been competition between the herring and pilchard stocks, in their juvenile stages. Thus it is suggested that the Plymouth herring fishery failed in competition with the pilchard stock and that the other biological events which took place in the early thirties were a consequence of this postulated competitive change.

\section{REFERENCES}

Armstrong, F. A. J., I954. Phosphorus and silicon in sea water off Plymouth during the years 1950 to I953. F. mar. biol. Ass. U.K., Vol. 33, pp. 381-92.

— 1955. Phosphorus and silicon in sea water off Plymouth during 1954. F. mar. biol. Ass. U.K., Vol. 34, pp. 223-8.

_ 1957. Phosphorus and silicon in sea water off Plymouth during 1955. F. mar. biol. Ass. U.K., Vol. 36, pp. 317-21.

—- 1958. Phosphorus and silicon in sea water off Plymouth during 1956. F. mar. biol. Ass. U.K., Vol. 37, pp. 37I-7.

AtKINs, W. R. G., I953. Seasonal variations in the phosphate and silicate content of sea water. Part VI. 1948 compared with the $1923-25$ period. F. mar. biol. Ass. U.K., Vol. 31, pp. 489-92.

Beverton, R. J. H., I96r. The long term dynamics of fish populations. F. Anim. Ecol. (in press).

BEVERTON, R. J. H. \& Holt, S. J., 1957. On the dynamics of exploited fish populations. Fish. Invest., Lond., Ser. 2, Vol. I9.

CoOPER, L. H. N., 1938. Phosphate in the English Channel, 1933-8, with a comparison with earlier years, 1916 and 1923-32. F. mar. biol. Ass. U.K., Vol. 23, pp. $18 \mathrm{I}-95$.

- 1948. The distribution of iron in the waters of the western English Channel. f. mar. biol. Ass. U.K., Vol. 27, pp. 279-313.

Corbin, P. G., I948. On the seasonal abundance of young fish. IX. The year 1947. F. mar. biol. Ass. U.K., Vol. 27, pp. 718-22.

- - 1949. On the seasonal abundance of young fish. X. The year 1948. F. mar. biol. Ass. U.K., Vol. 28, pp. 707-I2.

- - I95I. The seasonal abundance of young fish. XI. The year 1949. F. mar. biol. Ass. U.K., Vol. 30, pp. 27I-5.

Cushing, D. H., I957. The number of pilchards in the Channel. Fish. Invest., Lond., Ser. 2, Vol. 21, No. 5.

- $1959 a$. The seasonal variation in oceanic production as a problem in population dynamics. F. Cons. int. Explor. Mer, Vol. 24, No. 3, pp. 455-64.

- I959b. On the effect of fishing on the herring of the southern North Sea. f. Cons. int. Explor. Mer, Vol. 24, pp. 283-307.

ForD, E., 1933. An account of the herring investigations conducted at Plymouth during the years from 1924 to I933. F. mar. biol. Ass. U.K., Vol. I9, pp. 305-84.

HickLING, C. F., 1945. The seasonal cycle in the Cornish pilchard Sardina pilchardus Walbaum. F. mar. biol. Ass. U.K., Vol. 26, pp. II5-38.

KeMP, S., I938. Oceanography and the fluctuations in the abundance of marine animals. Rep. Brit. Ass. Adv. Sci., 1938, pp. 85-ror.

Matrhews, D. J., I9I7. On the amount of phosphoric acid in the sea-water off Plymouth Sound. F. mar. biol. Ass. U.K., Vol. II, pp. 25I-7. 
RICKER, W. E., I958. Handbook of computations for biological statistics of fish populations. Bull. Fish. Res. Bd. Can., No. I I9, 300 pp.

Russell, F. S., I926. The vertical distribution of marine macroplankton. II. The pelagic young of teleostean fishes in the daytime in the Plymouth area, with a note on the eggs of certain species. F. mar. biol. Ass. U.K., Vol. I4, pp. IoI-69.

- 1930. The seasonal abundance and distribution of the pelagic young of teleostean fishes caught in the ring-trawl in offshore waters in the Plymouth area. F. mar. biol. Ass. U.K., Vol. I6, pp. 707-22.

— I935. The seasonal abundance of the pelagic young of teleostean fishes caught in the ring-trawl in offshore waters in the Plymouth area. Part II. F. mar. biol. Ass. U.K., Vol. 20, pp. I47-79.

- I936. The seasonal abundance of the pelagic young of teleostean fishes in the Plymouth area. Part III. The year 1935, with a note on the conditions as shown by the occurrence of plankton indicators. F. mar. biol. Ass. U.K., Vol. 20, pp. 595-604.

1937. The seasonal abundance of the pelagic young of teleostean fishes in the Plymouth area. Part IV. The year 1936, with notes on the conditions as shown by the occurrence of plankton indicators. F. mar. biol. Ass. U.K., Vol. 21, pp. 679-86.

— I938a. On the seasonal abundance of young fish. V. The year 1937. F. mar. biol. Ass. U.K., Vol. 22, pp. 493-500.

— I938b. The Plymouth offshore medusa fauna. F. mar. biol. Ass. U.K., Vol. 22, pp. 4II-39.

— I939a. On the seasonal abundance of young fish. VI. The year 1938. F. mar. biol. Ass. U.K., Vol. 23, pp. 381-6.

- - 1939b. Hydrographical and biological conditions in the North Sea as indicated by plankton organisms. F. Cons. int. Explor. Mer, Vol. I4, pp. I71-92.

- 1947. On the seasonal abundance of young fish. VIII. The year 1946, June to December. F. mar. biol. Ass. U.K., Vol. 26, pp. 605-8.

\section{APPENDIX I}

The change in recruitment to the Plymouth herring fishery

The age-distributions sampled in the Plymouth herring fishery from 1924 to I93I have been published by Ford (1933). The full age-distributions from 1924 to 1935 are given in Table 2.

TABLE 2. AGE-DISTRIBUTIONS SAMPLED IN THE PLYMOUTH HERRING FISHERY AS CWT./ARRIVAL OF EACH AGE-GROUP

\begin{tabular}{|c|c|c|c|c|}
\hline \multirow[b]{2}{*}{ Year } & \multicolumn{4}{|c|}{ Age (years) } \\
\hline & 3 & 4 & 5 & 6 \\
\hline I924 & $2 \cdot 2$ & 4.7 & $22 \cdot 3$ & $6 \cdot 3$ \\
\hline 1925 & 0.9 & $3 \cdot I$ & $3 \cdot I$ & II $\cdot 3$ \\
\hline 1926 & 0.7 & 4.0 & 3.6 & $I \cdot 9$ \\
\hline I927 & 6.9 & 8.6 & I4.8 & 6.0 \\
\hline 1928 & 0.7 & $7 \cdot 6$ & $5 \cdot 3$ & $7 \cdot 6$ \\
\hline 1929 & 0.6 & $6 \cdot 3$ & 13.6 & $6 \cdot 2$ \\
\hline I930 & $I \cdot I$ & $3 \cdot I$ & $7 \cdot 5$ & 10.9 \\
\hline I93I & 0.5 & $1 \cdot 9$ & $2 \cdot 4$ & 3.8 \\
\hline 1932 & 0.9 & $2 \cdot 6$ & $4 \cdot 6$ & 4.0 \\
\hline I933 & 0.2 & 0.9 & $2 \cdot 6$ & $4 \cdot 4$ \\
\hline I934 & 0.3 & 0.1 & $2 \cdot 2$ & $2 \cdot 0$ \\
\hline I935 & 0.5 & 0.4 & 0.2 & $I \cdot O$ \\
\hline
\end{tabular}


(Note. The published material, I924-31, is of catches/unit effort based on returns from the merchants to Mr Ford. The unpublished material from 1932 to 1935 , in percentages, has been raised by average figures of cwt./arrival based on the Sea Fisheries Statistical Tables; the bias introduced is considered to be very much less than the variation in abundance.)

If the age-distributions given in Table 2 are averaged, it becomes clear that the most abundant age-group is the 5-year-old, and so recruitment is assumed to have been complete by this age. To calculate the yearly number of recruits, some estimate of fishing mortality $F$, and of natural mortality $M$, is necessary. Some evidence has been presented that the instantaneous natural mortality rate of Downs herring in the North Sea amounted to $0.15-0 \cdot 20$ (Cushing, $1959 b$ ). The natural mortality of the Plymouth herring is, of course, unknown, but this value (which is close to that estimated for the Dunmore herring by my colleague A. C. Burd) can reasonably be used; if this value is an underestimate, its effect in the calculation is to reduce the magnitude of the estimates of recruitment. As we are only concerned really with relative values from year to year this possible bias does not matter very much. From the estimates of abundance given in Table 2 (1924-35), it is possible to make rough estimates of total instantaneous mortality rates from 5 to 6 years old (i.e. $\log _{e} N_{5} / N_{6}$ is an estimate of total mortality from the numbers/unit effort at 5 years old, $N_{5}$, and those at 6 years old, $N_{6}$; the average value of total mortality, $Z=(F+M)$, found was $0.45)$.

Let the total number of fish at 3,4 and 5 years old be $n_{3}, n_{4}$ and $n_{5}$, respectively.

Let the number of recruits in each age-group, 3,4 and 5 , be $r_{3}, r_{4}$ and $r_{5}$; let the number of recruits appearing at 3,4 and 5 years be $r_{3}, r_{3.1}$ and $r_{3.2}$ as at 3 years of age. We require $r_{3}+r_{3.1}+r_{3.2}$, the total number of recruits as at 3 years of age, or $R_{3}$. Let $t$ be I year.

So

$$
\left.\begin{array}{rl}
r_{3} & =n_{3}, \\
r_{4} & =n_{4}-r_{3} e^{-Z t}, \\
r_{3.1} & =r_{4} \cdot e^{M t}=\left(n_{4}-r_{3} \cdot e^{-Z t}\right) e^{M t}, \\
r_{5} & =n_{5}-r_{4} \cdot e^{-Z t}-r_{3} \cdot e^{-2 Z t}, \\
r_{3.2} & =\left(n_{5}-r_{4} \cdot e^{-Z t}-r_{3} \cdot e^{-2 Z t}\right) e^{2 M t} .
\end{array}\right\}
$$

Fig. 2 shows $R_{3}$, the numbers of recruits as at 3 years of age from I92I to I930, the year being the year of birth of the year-class. There was a period of high recruitment from I92I to 1924, after which it became reduced. Two periods of poor recruitment may be distinguished, $1925-28$ and $1929-30$; the latter period is one of very poor recruitment indeed.

\section{APPENDIX II. RECENT CHANGES IN THE PILCHARD POPULATION}

Since 1949, age- and length-distributions are available as sampled at Newlyn. The lengths for age are shown in Table 3.

As did the North Sea herring in 1950-52, the pilchard has increased in length for age, the 2-year-olds by $\mathrm{I} .5 \mathrm{~cm}$, the 3 -year-olds by about $\mathrm{I} \mathrm{cm}$, and the 4 -year-olds by about the same. Associated with the increase in length from 1950 to 1952 , the two-ringed fish have become much more abundant, as shown in Table 4.

This change in recruitment is of the same character as that which took place in the 
East Anglian fishery in 1950-51. However, it is not possible to distinguish between an earlier age of first recruitment and increased representation following a growthchange selection; there are no ring-net or trawl samples in the later years as in 1949. It is suggested from an examination of Table 4 that in 1949 the four-ringers were fully recruited and that after that date the three-ringers were fully recruited, and indeed a large proportion have come in a year earlier. The evidence is not complete, but it must be pointed out that the analogy with the change in recruitment to the East Anglian herring at the same time was found to be most suggestive.

TABLE 3. MEAN LENGTHS (CM) OF PILCHARDS IN THE COMMONER AGE-GROUPS, I949-54

\begin{tabular}{ccccc} 
& \multicolumn{4}{c}{ Age (years) } \\
\cline { 2 - 5 } Year & 2 & 3 & 4 & 5 \\
1949 & $17 \cdot 44$ & $19 \cdot 04$ & $19 \cdot 87$ & $20 \cdot 21$ \\
1950 & $17 \cdot 71$ & $19 \cdot 82$ & $19 \cdot 92$ & $20 \cdot 66$ \\
1951 & $17 \cdot 94$ & $19 \cdot 48$ & $20 \cdot 28$ & $20 \cdot 79$ \\
1952 & 18.90 & $19 \cdot 81$ & $21 \cdot 62$ & 22 \\
1953 & $18 \cdot 67$ & $19 \cdot 74$ & $20 \cdot 22$ & $20 \cdot 86$ \\
1954 & $18 \cdot 95$ & $20 \cdot 23$ & $20 \cdot 80$ & $21 \cdot 15$
\end{tabular}

TABLE 4. AGE-DISTRIBUTIONS OF PILCHARD IN THE WESTERN CHANNEL AS CWT./ARRIVAL

\begin{tabular}{|c|c|c|c|c|c|c|c|c|}
\hline \multirow[b]{2}{*}{ Year } & \multicolumn{8}{|c|}{ Age (years) } \\
\hline & $2+$ & $3+$ & $4^{+}$ & $5+$ & $6+$ & $7+$ & $8+$ & $9+$ \\
\hline I949 & 3 & 135 & 320 & I 24 & I $8 \mathrm{I}$ & 213 & $5 I$ & 17 \\
\hline 1950 & 57 & 253 & I94 & 156 & 217 & 240 & 30 & I4 \\
\hline 1951 & 339 & 298 & 233 & 143 & 102 & 68 & 102 & 4 \\
\hline 1952 & I 44 & 182 & I47 & 158 & I7I & II 2 & 68 & $4 \mathrm{I}$ \\
\hline 1953 & 142 & I49 & 158 & 95 & 75 & 77 & IOI & 27 \\
\hline 54 & 85 & I34 & 229 & I49 & I44 & 45 & - & - \\
\hline
\end{tabular}

Pilchards are spawned in midsummer and the $l_{1}$ (the projected length of the first summer zone on the scale) is comparatively large, $8-10 \mathrm{~cm}$; this is rather like that of the East Anglian herring, which spawn in November and December and which are larger animals. Hence it is reasonable to assume that this value of $l_{1}$ represents more than a year's growth, perhaps 18 months'. In other words, it is unlikely that the first ring is laid down in the first winter of life, but in the second. For example, a fish hatched in the summer of 1954 would lay down its first ring in the winter of 1955-56 and its second in the winter of 1956-57. Consequently a two-ringed fish (2+) caught in the summer is about 3 years old. 